\title{
'Writing' small states: contextualizing the construct in the Arab Gulf
}

\author{
Larbi Sadiki $^{1} \cdot$ Layla Saleh $^{1}$ (D)
}

Accepted: 9 July 2021

(c) The Author(s) 2021

\begin{abstract}
How do IR scholars 'write' the Arab Gulf? In attempting to address this question, the focus is twofold: first, the 'small state' as a construct and second, its application to the study of Gulf small states. The article tries to grapple with issues inherent in such an enterprise by providing a critical assessment of recent scholarship on the topic, with special reference to Qatar and the UAE. The problematic comes to the fore in a context of these two countries' increasing regional and international visibility, as well as what seems to be renewed scholarly interest in small states, more generally. Specifically, this analysis primarily seeks to relativize the small state within the Arab Gulf sub-region, drawing attention to ontological and epistemological issues. In so doing, the article offers some heuristics for the writing of small states in the Arab Gulf. One suggestion put forward in the article is more scrutiny of the regional context; what is called here the 'hydrocarbon semi-periphery'; and misgivings (conceptual and empirical) concerning, respectively, the treatment of 'soft power,' mediation, and intervention. One parting idea to derive from this line of inquiry is its cautionary note against inflating the utility or the explanatory power of a catch-all 'small state' construct when it comes to non-Western settings.
\end{abstract}

Keywords Small state $\cdot$ Gulf countries $\cdot$ Qatar $\cdot$ UAE $\cdot$ Postcolonialism

\section{Introduction}

Nothing vitiates the explanatory power of a concept more than misuse. As a construct, existing consideration of the 'small state' in relation to Arab Gulf states causes inevitable confusion. This article problematizes the long-debated IR construct of small states. Research has inquired into the uniqueness of small states or

\author{
Layla Saleh \\ Layla.saleh@qu.edu.qa \\ Larbi Sadiki \\ larbiki@qu.edu.qa \\ 1 Qatar University, Doha, Qatar
}


small powers relative to 'great powers' (Rothstein 1968), as well as the (inconclusive) impact of smallness as size on democratic governance (Dahl and Tufte 1973). Because their resources are fewer than large states, 'joint action' is more likely among small states, East (1973) suggested, while Keohane (1969, 296) deemed them incapable of consequentially impacting the international system. Alternatively, small states can have 'big influence' upon allies such as the USA (Keohane 1971). Decades after these classic characterizations, work on 'small states' seems to center less on conceptual puzzles and more on the empirical trajectory of small states with unexpected international stature or influence. However, what happens when the small state construct is carried over into non-Western contexts, namely the Arab Middle East? In addressing such a question, this article seeks to parse the concept and its application, with special reference to wealthy small Gulf states Qatar and the UAE that have catapulted to regional and international prominence over the last two decades and especially since the 2011 'Arab Spring.' We engage in a critique of the application of the 'small state' concept to these prosperous rentier states. By selecting these two cases, we do not adopt here a kind of Qatar or UAE 'exceptionalism.' Instead, we seek to problematize the writing of small states by stressing salient features in Qatar and the UAE that are absent in the other three small Gulf states. Qatar's population stands around 2.8 million and a GDP of roughly $\$ 146$ billion in 2020, while the UAE's population nears 10 million and its GDP was \$421 billion in 2019. Neighboring small state Kuwait is also wealthy but has not engaged as visibly in regional and international politics, despite the soft power-like mediation efforts in the GCC blockade/crisis. Oman is not an oil-rich state, and Bahrain manifests patterns of sub-regional foreign policy dependency on Saudi Arabia. Thus, our choice of these two cases rests on empirical (wealthy Gulf small states with ascendant regional prominence and intervention) and intellectual (increasing scholarly interest in these two countries) grounds. The gist of the approach here emphasizes post/decoloniality, implicating not the small states Qatar and the UAE themselves, but their writing. The aim is not to simply present new empirical analysis but more probingly, to investigate the knowledge-practices of research on small states.

The travel of constructs from the West to the rest creates epistemological problems. Application of the concept in the Middle East and Gulf states in particular seems wanting. Sometimes, the usage of this IR terminology gets caught in ongoing political rivalries, as between Qatar and the UAE. Ours is not a suggestion to cast aside the 'small state' construct in the Gulf or elsewhere. Rather, it is a call to localized, qualified usage. The very concept of 'Gulf' is an irritant. Is the Gulf Persian or Arab? Are the GCC states 'quasi-states' or full sovereign states? At the levels of identity, society, polity, culture, and given the diversity within the sub-region, assumptions about the 'Gulf' and its states are open to question. These conceptual quandaries are compounded in discussions of Gulf small states. Even good scholarship can be pushed a bit to provide better accounts, rising to the occasion of the Gulf states' regional prominence. One challenge is striking a balance between critical conceptual treatment and empirical work through robust, intellectual reflection. The scholarly vocation involves transporting and applying concepts, a part of knowledgemaking. The corpus of knowledge on Gulf small states is incomplete, we argue. It calls for more incisive, rigorous research. Hence, in this special issue, our working 
definition of (Arab) Middle Eastern small states refers to those with (relatively) limited capacities and populations; trenchant colonizer/colonized frictions (politically, economically, culturally); embeddedness in the MENA regional context and its various contests and realignments; and continued 'penetration' by external powers, regional and international.

We open up the article with a critique of existing scholarship on small states, including with reference to Qatar and the UAE. Next, we argue for a critical and postcolonial/decolonizing approach to the study of small states. We then offer three empirically-based heuristics for critical consideration of Gulf small stateness: attention to the regional context, the quasi-dependencies of what we call the 'hydrocarbon semi-periphery,' and the exigencies of Gulf small state 'soft power.' The conclusion hints at the need to, however roughly, disaggregate small states to account for the variability and diversity of what is after all a construct, subject to nuanced revision with attention to spatio-temporal situatedness and context.

\section{Gulf small states: blind spots and unasked questions}

To a great extent and across theoretical schools, scholarship on the international politics of the Arab world and the Gulf states remains mired in Euro-American prisms. The 'decolonizing' agenda has instead focused on China, India, Latin America, and even Turkey (Fonseca 2019). Recent work on the Gulf small states exemplifies the limits of extant approaches that do not adequately interrogate constructs developed in other settings before transplanting them. Like modern (Westphalian) statehood, the malleable categorization of small states is Western in origin. Neumann and Gstohl (2008) trace this 'residual category' back to the 1815 Congress of Vienna (3-6). It is not surprising, then, that Gulf specificities pertaining to political (monarchical authoritarianism, with the qualified exception of Kuwait and Bahrain), economic (rentier), sociocultural (tribal and Islamic) systems and their situatedness in international hierarchies, stretch the limits of the 'small state' concept. Examinations of reigning epistemologies and ontologies - aided by a critical and postcolonial lens-thus precede the dilemma of which major IR theory is most fitting to study Arab/Gulf small states. For, as Braveboy-Wagner (2008) suggests, the heterogeneity of small states implies that there may be no singularly suitable theoretical approach to their study (8-15).

Through their increasing visibility and self-insertion into international arenas, the Gulf small states Qatar and the UAE may defy realist expectations of irrelevance stemming from perpetual (military) weakness. Yet the trajectories of their rapid emergence do not sit well with liberalism's emphasis on democratic values. Thurer's proposition that adherence to liberal human rights norms and "good-neighborliness and solidarity toward the international community" will enhance the potential standing of small states $(1998,42)$ does not seem quite relevant. Qatar and the UAE have become active players in international organizations from the UN to FIFA, but their track record in human rights leaves much to be desired (Katzman 2020b, c). Neither does a constructivist perspective on the international stature of small states Finland and Sweden who have earned as 
neutral 'norm entrepreneurs' in environmentalism, conflict resolution, and dispensation of aid (Ingrebtsen 2002), seem to apply. Rather, the Gulf states have since the 2011 uprisings become increasingly interventionist, knee-deep in a (sub)regional 'normlessness' from MENA war-making to the GCC blockade/crisis (Sadiki and Saleh 2020). Panke (2016) outlines the 'structural disadvantages' for small states acting within international bodies: small bureaucracies, limited expertise, and a smaller resource pool. These seem to apply to small states everywhere. However, EU small states confront specific governance challenges within an organization populated by EU democratic member states. "Capacity-building" for EU small states refers to establishing and strengthening links with Brussels to take advantage of its training and experts (Panke 2016, 204). No parallel Arab regional organization, whether the Arab League or the GCC, maintains such democratic institutions, or the sophisticated bureaucratic infrastructure to amplify small states' limited capacities. Additionally, GCC small states face a set of challenges distinct from the Small Caribbean States with their slow economic growth, poverty-stricken populations, low social spending, high public debt, expensive energy, and environmental vulnerability (OECED 2019). Reasons that Gulf small states are prone to "volatility" and fluctuating growth rates as indicated in the OECD report are more related to market hydrocarbon prices than to poor economic performance. GCC "structural imbalances" are of a different kind.

Understanding the range of behavior and achievements necessitates attention to capacities, institutions, and history of small states that uniformly enjoy 'legal sovereignty' but exhibit uneven levels of 'autonomy' (Baldachinno and Wivel 2020, 6-10). The small state construct must be localized and contextualized. There is no one type of small state. Yet work on Gulf small states tends to uncritically apply the concept to Qatar and the UAE. Handel's classic (2006 [1981]) notion of small states' 'derivative power' addresses some issues of dependency on larger states, fitting to the Gulf. Against the conventional wisdom of the time, he posits that as long as global demand is consistent, in the absence of an energy "substitute," and while cooperation persists, oil-producing states "are in an exceptionally strong position" (Handel 1981, 166). However, he exaggerates the case of oil-exporting states' relative strength as expressed in the 1973 OPEC embargo. As the decades since have shown, that was a one-off occurrence led by (middle or large state) Saudi Arabia. The rise of Gulf small states does not rest on the 'stick' of withholding access to oil. Cooperation between GCC oil-exporting states has largely evaporated.

Crediting the accession of small states Qatar and the UAE at least in part to newfound forms of power (e.g., 'soft') in a globalized world (Ulrichsen 2012) presents only a partial picture. It neglects the military-industrial scaffolding of petrodollars, arms sales, and US bases. It may underplay the extent to which the rapid ascendancy of these small states has overlapped with their involvement in regional wars. Iraq's 1991 invasion of Kuwait may have been instructive in the lesson it taught small states (Ulrichsen 2012, 8-9). But for scholars, Iraq is indicative in another sense. The watershed US occupation of 2003 should provoke important questions about how the emergence of US- 'protected' small Gulf states relates to the destruction of a powerful (large) Arab state-and subsequent regional unravelling, including post-2011. 
Another (more or less constructivist) focus has been on Gulf small state branding, a 'niche' in cultural production, mediation, and soft power. Inflated accounts of GCC states 'punching above their weight' seem to stop with tracing visibility (rather than effectiveness). Whether or not GCC small states have proved capable of achieving (positive) outcomes and influence (akin to the Scandinavian small states, or Singapore) in the MENA region appears to be granted secondary importance. In a very complimentary account, Peterson (2006) discusses Qatar's "branding" as a strategy geared toward "survival" (733) to "assur(e) [its] legitimacy " (748) since it may not be fully or consistently "viable" to carry out the defense, bureaucratic and governing functions of a state. Qatar's "niche exploitation" as international host of sporting events, regional and global conferences, a home-grown airline, and museums helps put it on the international map, he says. But has branding helped Qatar achieve 'legitimacy' (whatever he means by that!) even (sub) regionally? The 2017 blockade/crisis on Qatar by the Arab Quartet, lasting over three years until January 2021 (Ng 2021), might suggest otherwise. Kamrava (2013) traces Qatar's outsize influence not just to its wealth but also the 'vision' of its leaders. Simply, he overstates the case. His narrative of its 'subtle power' stemming from 'military protection,' 'money,' and 'agency' (11-13) in a 'durable and popular' authoritarian state (167) seems dated only a few years later. How much 'agency' does a state whose 'military protection' - like the other Gulf small states-takes the form of US bases, really exercise? Kamrava's book does not seem to address this question.

How far did what Kamrava dubbed Qatar's 'subtle power' extend to prevent or reverse the blockade/crisis, negotiate lasting reconciliation between the Palestinians, wage peace in a (unified) Sudan, or guide the wars in Libya, Syria, and Yemen to resolution? Baxter et al. (2018) link Qatar's mediation efforts (Darfur, Palestine, Yemen, Lebanon) to its status-seeking behavior. For them, the country has been "successful in its efforts at mediation" even as admittedly the said conflicts are ongoing (203). Despite exhibiting good will, does not a lack of success in peace-making, at least thus far, test the extent of small state influence? Designating mediation fruitful at first signing delinks it from conflict resolution, reducing it to merely a token achievement of the mediator. Is not mediation about ending violence, stanching bloodshed and reviving livelihoods? Of course, failure here involves not just mediators but also the parties involved, across conflicts.

Highlighting another domain, Ulrichsen (2015) remarks upon Gulf small states' "projection of cultural influence" through sponsoring international sporting events (FIFA, Formula One) and football teams and clubs via by airlines advertising (Qatar Airways and Emirates Airways). He contends that this is more than Gulf-Western relations of 'interdependenc[y]' in security and other 'common interests' (53). Here the domestic-international (national-global) link is under-theorized: how does this 'cultural influence' fit into the GCC rentier states' roles within the global capitalist system? Is buying influence equivalent to 'projecting' influence? Qatar and the UAE have focused on the development of specific capacities (FIFA infrastructure, luxury shopping, museums), while other basic domestic capacities remain arguably underdeveloped (scientific and medical expertise, democratic governance). A recent comparison between Qatar and the UAE's strategies geared at 'overcoming smallness' characterizes Qatar's 'Al Jazeera World' path as dependent on soft 
power, diplomacy, and mediation, contrasted with a UAE 'DP Effect' enacted in commercial takeovers via ports (Miller and Verhoeven 2020). While variations certainly exist between the two Gulf small states' foreign policies, much is left unsaid. The 2017 Doha-mediated 'four towns deal' in Syria, for the return of Qatari hunter hostages in Iraq, was predicated on a population swap, millions of dollars, and the uprooting of thousands of Syrians in an already war-torn country (Worth 2018). Apparently viewing this deal as an episode of 'pragmatism' and tolerant 'willingness to quite literally talk to everybody" (Miller and Verhoeven 2020, 12) is surprising. What are the costs of doing small state mediation? To what extent is diplomacy implicated in (proxy) military intervention? A critical rethinking of Gulf small states necessitates scrutiny of international hierarchies and quasi-dependencies (from petrodollars to arms transfers and bases), as well as modes and tools of influence and intervention. It calls for assessing trajectories of Gulf small states' regional ascendancy. The sheer penetration of MENA regional violence lends a normative urgency to any serious attempt to chart Gulf small state "influence." No peace prizes herebestowed or received.

\section{Considering ontology and epistemology}

Problematizing uncritical use of the small state construct in the Gulf context alerts us to issues of ontology (what they are) and epistemology (representations, knowledge-practices). Here, we adopt tenets of Frankfurt School-inspired critical IR theory, with its focus on international structures of (capitalist) domination, and its normative drive toward emancipation (Cox 1981). IR critiques of the material and ideational/ideological bases of the world capitalist system, however, may stop short of denaturalizing manifestations of cultural-racial violence and hegemony. Confronting the Euro-centrism of critical IR theory (Hobson 2007) is thus imperative in examining the (international) politics of a region as drenched in post/decoloniality as the Middle East. Post/decolonial IR can pick up where critical IR leaves off. It can investigate, for instance, the "impact of colonial practices on the production and representation of identities," including within global capitalism (Chowdhry and Nair 2002, 2). The main preoccupation of postcolonial theory is challenging the "universality of the categories" of social science, including core concepts such as sovereignty and the state (Seth 2013, 2). Importantly, a postcolonial take does not seek to expunge disciplines of their Western theoretical underpinnings, to replace them with pristine autochthonous variants. Gayatri Spivak is skeptical of the notion of a pure "indigenous theory" that would require "ignore[ing] the last few centuries of historical involvement" (1991, 69). Instead, she contends, the postcolonial critic engages in constant "negotiation," seeking to "change something that one is obliged to inhabit, since one is not working from the outside" (Spivak 1990, 70). The point then is not necessarily to refute or nullify the concept of small stateness in its realist, liberal, constructivist, or critical variants. Rather, the aim is to decenter the concept from its Euro-American moorings. It is to identify the silences in accounts of Gulf small states that seem to skip over relations of quasi-dependency with the USA, or a region fractured by the 2003 Iraq occupation and post-2011 wars. As Blaney and 
Tickner (2017) argue, the decolonizing project too often turns to issues of 'worlding" and epistemology_deficiencies and biases in representing via knowledge practices non-Western settings. They call on IR scholars to more seriously pursue the "reals" (in the plural)_ontologies - to defy assumptions of a "singular reality" that must simply be written in more localized ways, through better epistemological tools (Blaney and Tickner 2017).

Some scholars challenge the notion of a "universal sovereign state" born in Westphalia, entertaining different conceptualizations of statehood and sovereignty from the Islamic world, China, and Africa (Behera 2020). In turn, we dispute the notion of a singular or fixed small state. Instead, we posit that there are small states (plural). Scholars must begin to ask, what is the small state in the UAE or Qatar? The parlance 'small state' has no Arabic equivalent, or even a neologism. Arabicspeakers in the Gulf or the Arab region do not use the term dawlah saghirah (small state). This concept has been 'written' into Gulf existence, as in recent scholarship surveyed above. The demographic lopsidedness of these Gulf small states whose indigenous populations are a minority raises another question. When (class- and rights-stratified) migrant workers are effectively responsible for bureaucracies, construction, education, and healthcare, when highly paid Western consultants advise policymakers, how much of the small state is actually indigenous?

Existing work seems to conceptually skip the whole debate on whether or not the small states label fits, yet express confidence in use of the concept. We must ask about the extent to which IR constructs and theories reproduce unevenness between colonizer and colonized. Partly, an IR quasi-decolonizing impetus is in order. Problematizing IR constructs that ignore context-sensitivity entails moving toward decoloniality. As Maldonado-Torres puts it, this involves 'oppositions to the coloniality of power, knowledge, and being" (2007, 262). Countering coloniality enables us, for instance, to eschew universalizing constructs/theories, additionally considering them in their locales_making subalternity speak back and 'write back.' That is, a kind of bottom-up rereading and critiquing of constructs such as small states: almost representations from the periphery instead of about it. The need to sensitize IR and related disciplines and practices to new contexts is pressing. We do not speak here of neutral knowledge. These are fields of knowledge about power that at the same time display their own stamp of power given their provenance from formerly colonial sources.

Therefore, there is a need to appreciate the mutually constitutive nature of constructs from (Western) academia on the one hand and colonialism and coloniality on the other. We can interrogate, for instance, through 'border thinking" (Mignolo 2000), the continuity of subject-object, Occident-orient, self-other and West-rest dichotomies that perpetuate domination qua the putative power of knowledge. Authors must tackle constructs that masquerade as knowledge, taking for granted the transferability of knowing intact from the West to the rest-a form of domination. It is here that the contest over knowledge-making and meaning-making is as dangerous if left unresearched as geostrategic, economic or political domineering. This is because it touches on issues of self-definition, self-constitution and identity. It is alarming when the world of meaning of the formerly colonized is constructed by the colonizer's knowledge, as "wording" and "worlding." 
These structural problems cannot be ignored in scholarship on Gulf small states. Gulf specificities have essentially left them out of scholarship on the "Global South," amounting to a sort of epistemic exclusion (Ferabolli 2019). The task of post/decolonial critique is thus compound: first, deconstructing uses of the 'small state' concept and second, a recognition of power asymmetries and quasi-dependency. These Gulf small states emerged from the British protectorate system, already ensnared by dictatorial ruling families into oil contracts with the "Seven Sisters" in terms favoring Western powers. It is not a question, then, of small states seeking to maintain autonomy and confront the "deep penetration" by larger powers under whose wing they seek "alliance shelter" (Bailes et al. 2016, 6-7). For the Gulf small states, such autonomy never existed to begin with. Problematizing the very sovereignty of Gulf small states pushes a different reading of their stature. Charting the sites of Qatar and the UAE's quasi-dependency on Western powers implies analyses distinct from declarations of "subtle power" or impressive state branding.

The unavailability of reliable data in closed, undemocratic regimes adds epistemological challenges, casting into doubt some dimensions of how Gulf small states are 'written.' A critical, post/decolonial perspective prompts us to examine interlocking layers of regional context, hydrocarbon economies, and intervention/mediation. It allows for examining asymmetrical power relations between Gulf small states their Western 'allies.' The next section thus hints at some localized empirics, 'guideposts' and heuristics for to facilitate 'small state' decentering.

\section{Writing Gulf small states: missing pages}

\section{Regional context}

Rethinking small states requires contextualizing and historicizing how they have been 'written.' Empirical contextualization, or identifying how these concepts have (mis)traveled from the West to the Gulf, is equally significant. For, "appropriate empirical research is a crucial part of an active decolonizing project" (Sabaratnum 2011, 783). It involves careful attention to spatio-temporal contexts. It is not farfetched to conclude that MENA and the Gulf specifically have been home to "perpetual war," since Iraq's invasion of Kuwait in 1990-1991 (Abu Diyab 2019). The Gulf small states have been part of and imbricated in these wars. A significant turning-point for the region inclusive of the GCC (Al-Ubaydli and Plebani 2014) was the redrawing in blood, boots, and bases, of power configurations through the 2003 US invasion of Iraq. Qatar and the UAE's rise would be inconceivable without this war. It ushered in new models of state failure, sectarian violence, and multi-sided state (and non-state) interventions. The gigantic American 'footprint' in the region destroyed the Iraqi state and heralded new regional realignments (especially vis-àvis Iraq and Iran). It is no coincidence that Qatar is home to US Central Command, so crucial to the 'War on Terror.' Further, the 2011-Arab Spring uprisings became arenas for small states to flex their military and diplomatic muscle (Libya, Syria, Yemen, Egypt). In so doing, Qatar and the UAE stepped into spaces that had never been part of their theater of operations, where previously, regional intervention had 
taken the forms of nationalism, socialism, etc. Through their alleged links with militias (e.g. Ardemagni 2017; Ulrichsen 2014, 127-128), sponsoring of opposition conferences, diplomatic summits, and acting as go-betweens with both the USA and larger 'middle powers' such as Turkey and Iran, they fill a void in a region marked by the retreat of traditional powers (Egypt, Iraq, Syria).

Arab Spring dynamics also became bones of contention between Gulf (small) states themselves. Hence, the 2017 blockade/crisis on Qatar, including by two sister small states, Bahrain and the UAE (Milton-Edwards 2020), marked another turningpoint in (sub)regional relations. Turkey and Iran's positions, interpreted as being pro-Qatar (Aljazeera Centre for Studies 2017), have been consequential. Contests with Iran may no longer top the list of rivalries in the Arabian Peninsula. The viability of the GCC, established in 1981 as a strategic alliance to fend off Iran, is questionable cleaved as it is by internal conflict. The publicly declared conclusion to the crisis may not mask lingering "rivalry" with respect to regional relations (Turkey, Iran) and positions (Tunisia, Libya) (Ramani 2021) or relations with Israel (Neubauer 2020). Furthermore, the 2017-2021 Gulf split played out in broader regional interventions, and stances: the new 'axis politics' (siyasat al-mahawir). The UAE and Qatar duel it out across the Middle East with their respective allies (e.g., Egypt and Turkey). These competing but unstable regional 'axes' in turn influence political debates (Tunisian parties), military dynamics (Haftar vs. Sarraj in Libya), and diplomatic postures (rapprochement or freezing toward Syria's Assad). Even in the Horn of Africa, the two countries have taken opposite sides in the Somaliland-central government conflict in Somalia (Kinninmont 2019, 31). Another facet of the competition between the UAE and Qatar involves the cultural domain and the projection of ideas. With the means to hire regional and international cadres, for the first time they leave their imprint on intellectual and cultural narratives and debates across different outlets: newspapers, television, online publications, even research centers.

Most bloodily, (sub)regional rivalries feed the 'new proxy warfare.' State and non-state actors "cros[s] red lines and bend international norms," thriving on secrecy to shield the illicit funding, arms funneling, and subsequent violence from any sort of public scrutiny (Rondeaux and Sterman 2019, 3). Such rivalries ricochet back to not only entrench intra-Gulf discord, but it seems, the small state ambitions of Qatar and the UAE in particular. At the same time, these small states attempt to demonstrate 'bigness' not just globally, but also regionally - trying to transcend two levels of smallness. Qatar, which tries continually to assert itself outside the shadow of regional 'big brother' Saudi Arabia, has not been able to maintain its hold on some major regional issues since 2011. If Qatar did exhibit conservatism, avoiding "overstep[ping] the boundaries" vis-à-vis the Kingdom (Khatib 2013, 419) that did not last (or work) for long. As the former Qatari Prime Minister Hamad bin Jassim tells it, Saudi Arabia decided it "wanted us [Qatar] in the back seat. We ended up competing [regionally] and it was not healthy" (Khalaf 2016). Qatar had initially hosted members and conferences of the Syrian opposition including the formation of the Etilaf, until Riyadh decided to snatch back the Syria file, hosting the High Negotiations Committee and the Riyadh I and II conferences, for example. Proving 'bigness' is harder than it looks, when Gulf small states arguably are unable to maintain even regional initiative they sought to exhibit. The point is not only that the 
Gulf small states did not emerge in a vacuum. The regional context and the dilapidated larger states upon whose weakness these small states' centrality rests are a far cry from the Scandinavian small states neighboring the EU. It is distinct from dynamics in which Finland (Browning 2006) or Georgia (Gvalia et al. 2013) contend with US-Soviet/Russian polarities.

\section{'Hydrocarbon Semi-periphery'}

A seeming incommensurability between the respective emphases of postcolonialism (representation/culture) and dependency (imperialism/capitalism) does not preclude a complementarity between these two critical schools that both "shift the focus to the "periphery" (Kapoor 2002, 653). That is the approach adopted here. We tentatively conceptualize the Gulf small states as a 'hydrocarbon semi-periphery' in both the representational (Orientalist) and material (global capitalist) senses. Coloniality/ postcoloniality is an uneven terrain, within and outside the Middle East. Many Latin American states, formally independent from Spain or Portugal since the early nineteenth century, now have ties with the USA more consequential than those with their former colons (Randall 2004, 42). A similar pattern may be observable in the small Gulf states, colonized by the British but whose economies (currencies pegged to the dollar) and security "umbrella" are underpinned by relations of what may be termed quasi-dependency. To an extent, we observe over the decades an asymmetrical relationship, a "situation in which the economy of certain countries is conditioned by the development and expansion of another economy to which the former is subjected" (Dos Santos 2002, 231). In this case, the relationship is between the rentier Gulf states and Western capitalist forces (especially the USA and its multinationals). However, the degree of constraints on the Gulf (small) states' economies may shift over time given the importance of oil and the fluctuation of oil prices in the global economy. Moreover, quasi-dependency — and the hydrocarbon semi-peripheralityof Gulf small states also takes security dimensions. This "security dependency" on Western states amounts to increased "Western political-security penetration" in the Gulf region (Hinnebusch 2003, 42-52). The so-called US security umbrella, has not waned with time, dissipated with oil booms or busts, or even been shaken much by the global COVID pandemic.

This accounts for both the participation (and culpability) of the small Gulf states via their rentier economies in (exploitations of) global capitalism, even as they themselves are affixed to the US economic and military powerhouse. Through their abundant capital, the Gulf states are major players and underwriters of capitalism both globally and regionally, as patterns of accumulation and (re)investment also intersect with the financing of violence across the Middle East (Hanieh 2018). 'Petrodollar recycling' is a case in point. Since the Gulf states nationalized their oil companies in the 1970s, revenue from oil sales has flowed back to banks in Europe and North America, helping prop up the USA as the "dominant global power" by anchoring the US dollar as the global reserve currency (Hanieh 2018, 34). The Gulf arms bazaar itself is a prominent mechanism of this petrodollar recycling (Hanieh 2018 , 58). These countries defy global trends of stabilizing arms sales. A $361 \%$ 
increase in Qatar arms imports in 2016-2020 compared to the previous five years, and UAE's earnestness in acquiring 50 US-made F-35 planes, are only the latest examples (SIPRI 2021). In this way, the small Gulf states through their US bases and astounding arms purchases, exhibit unique patterns of quasi-dependency perhaps more acute than with larger Gulf state Saudi Arabia.

Oil has given these small states potential international capacity. Qatar is among the top LNG (liquefied natural gas) producers in the world, opening up bidding with major oil companies to expand output through its North Field, even in the wake of COVID contractions (Bousso and Zhdannikov 2021). The UAE's petroleum exports stood at $\$ 49.636$ billion in 2019 , with oil and gas comprising about $30 \%$ of its GDP (OPEC 2021). In theory, hydrocarbon wealth represents a degree of independence, regionally from 'big brother' Saudi Arabia, and also globally. Why, then, do we observe some kind of misuse of the resource that could furnished a level of autonomy? Instead, oil and natural gas have become a restrictive or restraining variable. Economically, hydrocarbon wealth did not promote rapid diversification. Politically, a similar dynamic is present. The Gulf small states remain quasi-dependent on the global/Western 'flow' of oil, while upholding international capitalism, albeit where China carves out a larger space. The economic, the political, and the military converge. The hydrocarbon market meant links to the West: political, geostrategic, diplomatic. For us, the concept of 'quasi-dependency' taps into increased reliance on the West, and particularly the USA. The flow of oil needs the West, the sale of oil needs the West, the protection of oil producers needs the West. Complications ensue. The small Gulf states are no longer satisfied with indirect protection. Bases now become the source of American security 'shelter,' cementing a sort of quasidependency on the USA. We see this in the Al Dhafra Air Base and the 3500 US troops in the UAE (Katzman 2020c). Similarly, 8,000 US troops are stationed in Qatar, including at Al-Udeid upon which Qatar has lavished \$8 billion since 2002, preparing for $\$ 1.8$ billion more, hoping to achieve an "enduring" presence of the US military (Katzman 2020b, 15-18). The small Gulf states, then, appear entangled in asymmetrical power structures from which they cannot or do not extricate themselves. Western penetration and control extends from classified Defense Security Agreements with the USA to a Justice Resident Legal Advisor from the USA implanted in Doha since 2018 (Katzman 2020b, 19-20) and the FBI "Legal Attache" in Dubai since 2012 to coordinate counterterrorism efforts (Katzman 2020a, 18).

These features of Qatar and the UAE's foreign policies and economies prompt us to problematize small state sovereignty and autonomy. Students of the Gulf subregion are called upon to critically assess reference to one country's foreign policy as "independent" (Qatar), and to another as a "model" (UAE). Bearing in mind the characteristics recounted above can help contextualize discussions of the latter, for instance, as a more assertive small state that is "confident," willing to take risks in military campaigns and bases, a "developmental autocracy" comparable to Russia or China (Salisbury, 2020). We can observe some latitude to act regionally and globally carved out through financial largesse (e.g., cultural production). When we connect the dots, however, there are always constraints. The USA seeks to contain these small Gulf states, in effect shaping the contours of much of their regional policy, 
from various iterations of the War on Terror (Afghanistan-Iraq-ISIS, etc.) to training and counterterrorism. Such cooperation may serve to soften accusations of bankrolling extremist armed groups in Syria or Libya (for instance, in Dickinson 2014). There appears to be little space for independent regional maneuvering by these Gulf small states, who remain on the 'hydrocarbon semi-periphery.' Albeit with a euphemistic designation of the relationship ("cooperation" that we argue is more aptly termed "quasi-dependency"), a Congressional report offers a clear assessment: "The UAE's ability to project power in the region is a product of many years of US-UAE defense cooperation" (Katzman 2020a, 13). Without the USA' sovereignty-compromising military presence and "assistance," paid for by the UAE's (and Qatar's) petrodollar purchasing power, these Gulf small states would have little regional "power" to speak of.

\section{Soft power, mediation and intervention}

The Gulf small states have been celebrated for projection of "soft power." This label, however, is arguably a misappropriation. Nye's (2004) "power of persuasion," derived from the US case, is conceptualized as an alternative or a complement to hard (military) and economic power. Soft power is no stand-alone power. Yet its application to the small Gulf states implies just that. Cultural burden-sharing (hosting of international sporting events such as FIFA), humanitarian and development aid (to Katrina victims, or COVID assistance (Crisis Group 2020)), and presence in diplomatic circuits is rendered almost unreflexively as an accumulation or wielding of soft power. This is conceptually and empirically problematic. "The ability to get what you want through attraction rather than coercion or payments [that] arises from the attractiveness of a country's culture, political ideals, and policies." (Nye 2004, $\mathrm{x})$ seems not to ring a bell where the small Gulf states are concerned. They do not have the base of values (e.g., democratic), attractive foreign policy (e.g., convincingly peace-promoting), or independent military means from which to launch "soft power." The concept does not seem to translate well to the Gulf small states. It is not enough for scholars to mention that the Gulf small states are not democratic, and then proceed to tack on the soft power label. Democracy and soft power are in fact interrelated issues: soft power is supposed to be a projection of normatively positive attributes, policies, models, ideas.

Yet the putative soft power of Gulf small states may be another story. On the one hand, interventionism seems to be the other side of the soft power coin. Before it withdrew its forces upon the 2017 blockade/crisis, Qatar was part of the Saudiled war in Yemen, even announcing its own military casualties (Aljazeera 2016). However, it is the UAE's consistent trajectory of military interventionism that stands out. After extensive international criticism for human rights violations in the Saudi-led Yemen war (HRW 2020), at the time of writing, the UAE had scaled down its involvement. But in a 2018 offensive, the UAE occupied the Yemeni island of Socotra, setting up a base (Towers 2018) and supporting Southern Transitional Council forces there. Prior to the October 2020 ceasefire agreement, the UAE had also inserted itself into the Libya war, through military support to Haftar, alongside 
a new Egyptian military base-opposite Turkish-backed support for the internationally-recognized Government of National Accord (Dorsey 2020a, b). This in addition to UAE military bases in Eritrea and Djibouti (Salisbury 2020). Such militarism does not square well with the generally positive attributes attached to small states.

On the other hand, even the domain of soft power as (effective) mediation itself is dubious in the case of the small Gulf states. Exercising what seems to be selfappointed guardianship over Palestine, the UAE also pursues a sort of mediation. Its new "normalization" with Israel makes "less likely" any viable or just peace premised on the long-deferred "two state solution" ending Israeli occupation (Black 2020). While reflecting goodwill, Qatar's mediation has not so far been successful at resolving conflict. Note the political instability and economic disaster in 2020-21 Lebanon, a split Sudan/South Sudan, war-torn Syria, and 'post-conflict' Libya where two small Gulf states clashed on opposite ends of the political, diplomatic, and military conflagrations. Time will tell whether the February 2020 US-Taliban agreement, mediated by Qatar, will hold. Where it mattered most, 'peace' has not reigned in its own neighborhood, as exemplified in the 2017 blockade/crisis. Some have characterized it as an illustration of "resilience" (Ulrichsen 2020). However, despite deepening alliances with regional powers such as Turkey (Başkan and Pala 2020), Qatar was unable to protect itself, or sidestep its vulnerability to fend off this episode. Where, then, was the much-vaunted soft power?

More fundamental is the element of quasi-dependency inherent even in attempts, however well-intentioned, to project soft power. Whose power does it amplify? Just as observers might ask: oil and gas are ultimately resources for whom? One attempt at refiguring soft power in Qatar adds "disempowerment" variables (e.g., international criticism) (Brannagan and Guilanotti 2018). This account may add complexity to understanding soft power in a non-Western context. However, it treats US bases - a cornerstone of what we consider a sort of security dependency-as among the "matrix of foreign relationships" that comprise its soft power resources (Brannagan and Giulianotti 2018, 1149). The question becomes: soft power for whom? Even in the religious domain, an indigenous niche for Muslim countries including Gulf small states, Qatar's generally pro-Islamist policies remain circumscribed in the case of supporting Hamas, for instance, by the "direct blessing of the USA and pragmatic assistance from Israel” (Roberts 2019, 7). The UAE's Forum for Promoting Peace in Muslim Societies has hosted US officials preaching religious freedom (US Department of State 2018). US geostrategic objectives and constraints, from religion and tolerance to mediation (Darfur, Hamas, the Taliban), are never far behind. Handel's “derivative power" of small states (1981) is useful here. These Gulf small states never seem to wield more than derivative power or what may be called proxy soft power. Recent reports of lobbying contests in Washington, with the UAE and Qatar spending a combined $\$ 100$ million since mid-2017 (Pecquet 2020), drive home the point. In this proxy soft power, both the UAE and Qatar attempt not to sell, but to buy their narrative (counterterrorism force vs. good ally, respectively), to convince a great power on which they are both quasi-dependent of the legitimacy of their stances vis-à-vis one another. Rather than exerting soft power (sub)regionally in pursuit of intra-GCC conflict resolution, both lobby their Western "security provider" that for years failed to resolve the 2017-2021 blockade/crisis. 


\section{Concluding thoughts: toward disaggregation of small states?}

Through a focus on the Gulf countries Qatar and the UAE, this article has proposed critical reconsiderations relevant to 'writing' small states. The crux of our argument regards knowledge-making practices, not sizing up specific small states and their policies, or taking sides in intra-regional disputes. That is, how we conceptualize and apply concepts: defending the choice of 'wording' so that we can engage in better 'worlding.' The idea is to avoid a kind of 'over-stating' the state, to invoke Ayubi's (1995) term, that under-states small state theory. Since small states are neither singular nor fixed, the concept should not be adopted mechanically wholesale in Arab contexts. The decolonizing trajectory mandates historicized, contextualized, and localized readings of small states. Even within the Gulf, small states can vary. Arguably, the most interventionist, the UAE is an aggressor whose 'second-hand' military prowess is circumstantial, stemming from geostrategic interests of superpowers (the USA) preoccupied with Iran, Israel, and oil, within a former colonial heartland. Moreover, Qatar is not Oman. Hence, within the small, wealthy Gulf states, further comparisons are needed. Kuwait, for instance, shares with Qatar and UAE the presence of US bases and troops since 1991: 13,000 at last official count (Katzman 2020a). It is attempting economic diversification. Yet there are questions about whether or not Kuwait has the funds to complete a planned megacity project costing about $\$ 100$ billion (Gorvett 2019). At the same time, there may be a (quasi) democratic distinction: Kuwait's project has lagged partly due to anti-corruption protests and "political paralysisl" in parliament (MacDonald 2019). Such expressions of popular discontent, and a modicum of legislative checks on executive decisions, are as of yet nonexistent in the UAE and Qatar. (The latter has its Shura Council elections planned for October 2021.) Even in the Gulf, the rentier small states are not all the same, in their domestic (non)distribution of power and the ways it feeds into economic and foreign policies.

Generally, 'small states' have a positive reputation. For instance, as 'norm entrepreneurs,' Scandinavian small states are neutral, mediate disputes, stay out of conflicts, and cultivate peace initiatives. Outside the West, Costa Rica has made a name for itself as a democratic small state promoting human rights (Brysk 2005). Financial hub Singapore is synonymous with investments in human capital that have paid off in its knowledge economy (Wong et al. 2007). The Gulf small states occupying the 'hydrocarbon semiperiphery' in the global hierarchy, not untouched by COVID's economic repercussions (Dorsey 2020a, b), instead participate in aggression (UAE), or struggle with mediation (Qatar). They rely on ample purchasing power (including the UAE's expanding control of ports), as states whose very sovereignty is in question under the US 'security umbrella.' Most importantly, these two small states have no democratic pedigree to speak of (Sadiki 2020). They are wanting in institutionalized power-sharing arrangements that could reign in aspirations induced by whatever money can buy-in dollars. It helps the Gulf's rulers that the USA, despite "accusations of hypocrisy," more or less prefers 'stability' to democracy in the sub-region (Gause 2013, 2). Qatar and the UAE, then, are examples of countries that present scholars with ontological, epistemological, and normative 'tests' of the small state construct. In recent years, these Gulf states have asserted themselves as the new interveners, power brokers, and above all 
funders of the shifting post-2011 regional order. Somehow, modifiers like 'mediator,' 'moderate, 'tolerant,' or, 'peacemaker,' do not seem to square with rising levels of violence, human casualties, mass displacement, burgeoning inequality. With the rise of the small Gulf states, we also witness greater international intervention as France, Russia, China, and others (Iran, Turkey) all stake claims in regional power voids. Gulf small state 'emergence' is certainly noteworthy. Whether it feeds into regional accord or discord is a question to be taken up, we hope, by researchers who look beyond 'state branding,' or self-styled 'little Spartas,' as they critically (re)‘write' small states.

Funding Open access funding provided by the Qatar National Library.

Open Access This article is licensed under a Creative Commons Attribution 4.0 International License, which permits use, sharing, adaptation, distribution and reproduction in any medium or format, as long as you give appropriate credit to the original author(s) and the source, provide a link to the Creative Commons licence, and indicate if changes were made. The images or other third party material in this article are included in the article's Creative Commons licence, unless indicated otherwise in a credit line to the material. If material is not included in the article's Creative Commons licence and your intended use is not permitted by statutory regulation or exceeds the permitted use, you will need to obtain permission directly from the copyright holder. To view a copy of this licence, visit http://creativecommons.org/licen ses/by/4.0/.

\section{References}

Abu Diyab, K. Halat Al-Harb Al-Da'imah fil Khalij [The State of Perpetual War in the Gulf.]. Monte Carlo Al-Duwaliyyah, (2 June 2019), https://www.mc-doualiya.com/chronicles/decryptage-mcd/ 20190206-\%D8\%AD\%D8\%A7\%D9\%84\%D8\%A9-\%D8\%A7\%D9\%84\%D8\%AD\%D8\%B1\%D8\% A8-\%D8\%A7\%D9\%84\%D8\%AF\%D8\%A7\%D8\%A6\%D9\%85\%D8\%A9-\%D9\%81\%D9\%8A-\%D8\% A7\%D9\%84\%D8\%AE\%D9\%84\%D9\%8A\%D8\%AC-\%D8\%A7\%D9\%84\%D8\%B4\%D8\%B1\%D9\% 82-\%D8\%A7\%D9\%84\%D8\%A3\%D9\%88\%D8\%B3\%D8\%B7, accessed 26 August 2020.

Aljazeera. (2016) Maqtal Thalathat Junud Qatariyin bil Yemen [Three Qatari Soldiers Killed in Yemen], 12 September, https://www.aljazeera.net/news/arabic/2016/9/13/\%D9\%85\%D9\%82\%D8\%AA\% D9\%84-\%D8\%AB\%D9\%84\%D8\%A7\%D8\%AB\%D8\%A9-\%D8\%AC\%D9\%86\%D9\%88\%D8\%AF-\% D9\%82\%D8\%B7\%D8\%B1\%D9\%8A\%D9\%8A\%D9\%86-\%D8\%A8\%D8\%A7\%D9\%84\%D9\%8A\% D9\%85\%D9\%86, accessed 5 September 2020.

Al Jazeera Centre for Studies. (2017). Policy Brief: Effects of the Gulf Crisis on Regional Balances, 26 September, https://studies.aljazeera.net/en/positionpapers/2017/09/effects-gulf-crisis-regional-balan ces-170926093056154.html, Accessed 26 August 2020.

Al-Ubaydli, O., and A. Plebani, eds. 2014. GCC Relations with Post-War Iraq: A Strategic Perspective. Cambridge: Gulf Research Centre Cambridge.

Ardemagni, E. 2017. UAE-Backed Militias Maximize Yemen's Fragmentation. Istituto Affari Internazionali (IAI), 29 August. https://www.iai.it/en/pubblicazioni/uae-backed-militias-maximize-yemensfragmentation. Accessed 16 July 2021.

Ayubi, Nazih. 1995. Over-Stating the Arab State: Politics and Society in the Middle East. London: I.B. Tauris.

Bailes, A., B. Thayer, and B. Thorhallson. 2016. Alliance Theory and Alliance "Shelter": The complexities of small state alliance behavior. Third World Thematics: A TWQ Journal 1 (1): 1-18.

Baldacchino, Godfrey, and Anders Wive. (2020) "Small States: Concepts and Theories." In Handbook on the Politics of Small States, ed. Godfrey Baldaccino and Anders Wivel. Cheltenham: Edwar Elgar.

Behera, Navnita Chadha. (2020) State and Sovereignty. In: Eds: Tickner, A. B. and Smith, K. International Relations from the Global South: Worlds of Difference. London: Routledge, pp 139-160

Black, I. (2020) The UAE-Israel Deal will Make a Two-State Solution Even Less Likely. The Guardian, 14 August, https:/www.theguardian.com/commentisfree/2020/aug/14/ 
the-israel-uae-deal-will-make-a-one-state-solution-even-more-unlikely, Accessed 4 September 2020.

Brysk, Alison. 2005. Global Good Samaritans? Human Rights Foreign Policy in Costa Rica. Global Governance 11 (4): 445-466.

Bousso, R. and D. Zhdannikov. 2021. "Exclusive: Energy Majors Bid for Qatar LNG Project Despite Lower Returns." Reuters 14 June, https://www.reuters.com/business/energy/exclusive-energymajors-bid-qatar-lng-project-despite-lower-returns-2021-06-13/, Accessed 28 June 2021.

Baxter, P., J. Jordan, and L. Rubin. 2018. How Small States Acquire Status: A Social Network Analysis. International Area Studies Review 21 (3): 191-213.

Blaney, D.L., and A.B. Tickner. 2017. Worlding, Ontological Politics and the Possibility of a Decolonial IR. Millennium: Journal of International Studies 45 (3): 293-311.

Başkan, B., and Ö. Pala. 2020. Making Sense of Turkey's Reaction to the Qatar Crisis. The International Spectator 55 (2): 65-78.

Brannagan, P.M., and R. Giulianotti. 2018. The Soft-Power-Soft Disempowerment Nexus: The Case of Qatar. International Affairs 94 (5): 1139-1157.

Braveboy-Wagner, J. 2008. Small States in Global Affairs: The Foreign Policies of the Carribean Community (CARICOM). Basingstoke: Palgrave-Macmillan.

Browning, Christopher S. 2006. Small, Smart and Salient? Rethinking Identity in the Small States Literature". Cambridge Review of International Affairs 19 (4): 669-684.

Chowdhry, G., and S. Nair, eds. 2002. Power: Postcolonialism, and International Relations. London: Routledge.

Cox, R.W. 1981. Social Forces, States and World Orders: Beyond International Relations Theory. Millennium: Journal of International Studies 10 (2): 126-155.

Dorsey, Jean Muir. 2020. Lessons Gulf States Have Learned from Coronavirus Pandemic. WIONews, 28 May, https://www.wionews.com/opinions-blogs/lessons-gulf-states-have-learned-from-coronaviruspandemic-301605, accessed 30 June 2021.

Fonseca, M. 2019. Global IR and Western Dominance: Moving Forward or Eurocentric Entrapment? Millennium: Journal of International Studies 48 (1): 45-59.

Dahl, R., and E. Tufte. 1973. Size and Democracy. Stanford, CA: Stanford University Press.

Dickinson, Emily. (2014). The Case Against Qatar, Foreign Policy, 30 September, https://foreignpolicy. com/2014/09/30/the-case-against-qatar/, accessed 5 September 2020.

Dorsey, J. (2020). The Battle for Libya: The UAE Calls the Shots. Medium, 18 January, https://medium. $\mathrm{com} /$ the-turbulent-world-of-middle-east-soccer/the-battle-for-libya-the-uae-calls-the-shots-43e $4 \mathrm{~d}$ 7dcf4e0, Accessed 31 August 2020.

Dos Santos, T. 1970. The Structure of Dependence. The American Economic Review 60 (2): 231-236.

East, M. 1973. Size and Foreign Policy Behavior: A Test of Two Models. World Politics 25 (4): 556-576.

Gorvett, Jonathan. (2019) Kuwaiti Megaproject Faces Investment Challenges at Home and Abroad, Gulf Monitor, 10 December, https://castlereagh.net/kuwaiti-megaproject-faces-investment-challenges-athome-and-abroad/, Accessed 31 August 2020.

Handel, Michael I. (2006 [1981]). Weak States in the International System. In: C. Ingebritsen, I. Neumann, S. Gstohl, and J. Beyer (Eds): Small States in International Relations. Seattle and Reykavik: University of Washington Press and University of Iceland Press: Seattle and Reykavik, pp. 149-192.

Ferabolli, Silvia. (2019) Do the Arab Gulf States belong to the South? Mundorama - Revista de Divulgação Científica em Relações Internacionais, https://www.lume.ufrgs.br/bitstream/handle/10183/ 203676/001086773.pdf?sequence=1, Accessed 29 August 2020.

Gause, Gregory F. (2013). Kings for All Seasons: How the Middle East's Monarchies Survived the Arab Spring. Brookings Doha Center Analysis Paper 8, file:///Users/lswriter/Downloads/Kings_ for_All_Seasons_How_the_Middle_Eas.pdf, accessed 4 September 2020.

Gvalia, Girogi, David Siroky, Bidzina Lebanidze, and Zurab Iashvili. 2013. Thinking Outside the Bloc: Explaining the Foreign Policies of Small States. Security Studies 22 (1): 98-131.

Hobson, J.M. 2007. Is Critical Theory Always for the White West and for Western Imperialism? Beyond Westphilian Towards a Post-Racist Critical IR. Review of International Studies 33: 91-116.

Hinnebusch, Ray. 2003. The International Politics of the Middle East. Manchester: Manchester University Press. 
Human Rights Watch. (2020) Yemen: Wartime Abuses Face Global Spotlight, 14 January, https:// www.hrw.org/news/2020/01/14/yemen-wartime-abuses-face-global-spotlight, Accessed 5 September 2020 .

Khatib, L. 2013. Qatar's Foreign Policy: The Limits of Pragmatism. International Affairs 89 (2): 417-431.

Ingrebetsen, C. 2002. Norm Entrepreneurs: Scandinavia's Role in World Politics. Cooperation and Conflict 37 (1): 11-23.

International Crisis Group. 2020. COVID-19 and Conflict: Seven Trends to Watch. 24 March. https:// www.crisisgroup.org/global/sb4-covid-19-and-conflict-seven-trends-watch, accessed 30 June 2021.

Kapoor, I. 2002. Capitalism, Culture, Agency: Dependency versus Postcolonial Theory. Third World Quarterly 23 (4): 647-664.

Kamrava, Mehran. 2013. Qatar: Small State, Big Politics. Ithaca and London: Cornell University Press.

Katzman, Kenneth. (2020a) The United Arab Emirates (UAE): Issues for US Policy, 7 August, https:// fas.org/sgp/crs/mideast/RS21852.pdf, accessed 27 August 2020.

Katzman, Kenneth. (2020b) Qatar: Governance, Security, and US Policy. 11 March. Congressional Research Service. https://fas.org/sgp/crs/mideast/R44533.pdf, accessed 17 August 2020.

Katzman, Kenneth. (2020c). Kuwait: Governance, Security, and US Policy. Congressional Research Service, June 3. https://fas.org/sgp/crs/mideast/RS21513.pdf [Accessed July 10, 2020]

Keohane, Robert O. 1969. Lilliputians' Dilemmas: Small States in Internatinal Politics. International Organization 23 (2): 291-310.

Keohane, R. 1971. The Big Influence of Small Allies. Foreign Policy 2 (Spring): 161-182.

Khalaf, R. Lunch with the FT: Sheikh Hamad Bin-Jaber Al-Thani, Financial Times, 15 April (2016), https://www.ft.com/content/98477922-0227-11e6-99cb-83242733f755, Accessed 15 August 2020

Kinninmont, Jane. (2019). The Gulf Divided: The Impact of the Qatar Crisis, Chatham House, https:// www.chathamhouse.org/sites/default/files/publications/research/2019-05-30-Gulf\%20Crisis_0. pdf, Accessed 31 August 2020.

Maldonado-Torres, Nelson. 2007. On the Coloniality of Being: Contributions to the Development of a Concept. Cultural Studies 21 (2-3): 240-270.

MacDonald, Francis A. (2019) Infrastructure and Reforms Stifled in Only Gulf State Where Voters Matter. Bloomberg, 7 November, https:/www.bloomberg.com/news/articles/2019-11-07/-silkcity-dream-stifled-in-only-gulf-state-where-voters-matter, Accessed 31 August 2020.

Mignolo, Walter D. (2000) Coloniality, Subaltern Knowledges, and Border Thinking. Princeton: Princeton University Press.Neumann, I. B. and Gstohl, S. (2006). Lilliputians in Gulliver's World? In: C. Ingebritsen, I. Neumann, S. Gstohl, and J. Beyer (Eds): Small States in International Relations. Seattle and Reykavik: University of Washington Press and University of Iceland Press: Seattle and Reykavik, pp. 3-36.

Miller, R., and H. Verhoeven. 2020. Overcoming Smallness: Qatar, the United Arab Emirates and Strategic Realignment in the Gulf. International Politics 57: 1-20.

$\mathrm{Ng}$, A. 2021. "End of Qatar Blockade is a 'Win for the Region,' Saudi Foreign Minister Says." CNBC, 6 January, https://www.cnbc.com/2021/01/06/end-of-qatar-blockade-is-a-win-for-the-regionsaudi-foreign-minister.html, Accessed 28 June 2021.

Milton-Edwards, B. 2020. The Blockade on Qatar: Conflict Management Failings. The International Spectator 55 (2): 34-48.

Neubauer, S. 2020. The Gulf Region and Israel. Old Struggles: New Alliances, New York, Kodesh Press.

Nye, J.S. 2004. Soft Power: The Means to Success in World Politics. New York: PublicAffairs.

OECD et al. (2019), "Special feature: The Caribbean small states", in Latin American Economic Outlook 2019: Development in Transition, OECD Publishing, Paris, https://doi.org/10.1787/a564a Obd-en.

Organization of the Petroleum Exporting Countries. 2021. "UAE Facts and Figures." https://www. opec.org/opec_web/en/about_us/170.htm, accessed 28 June 2021.

Panke, D. 2016. Small States in the European Union: Coping With Structural Disadvantages. London: Routledge. 
Pecquet, Julian. 2020. "Washington Lobbyists Continue to Cash in on Dispute Between Qatar and the UAE." Middle East Eye, 16 September 2020, https://www.middleeasteye.net/news/qatar-uaecontinue-lobbying-washington , accessed 20 September 2020

Peterson, J.E. 2006. Qatar and the World: Branding for a Micro-State. Middle East Journal 60 (4): $732-748$.

Ramani, Santhoshini Leela. 2021. The Qatar Blockade is Over, but the Gulf Crisis Lives On. Foreign Policy, 27 January, https://foreignpolicy.com/2021/01/27/qatar-blockade-gcc-divisions-turkeylibya-palestine/, accessed 30 July 2021.

Randall, V. 2004. Using and Abusing the Concept of the Third World: Geopolitics and the Comparative Study of Development and Underdevelopment. Third World Quarterly 25 (1): 41-53.

Roberts, David B. (2019). Reflecting on Qatar's 'Islamist' Soft Power. Policy Brief, Berkley Center for Religion, Peace and World Affairs, file:///Users/lswriter/Downloads/Islamist\%20soft\%20 power_FP_20190408_qatar_roberts\%20(1).pdf, Accessed 2 September 2020.

Rondeaux, Candace, and Sterman, Daniel H. (2019) Twenty-First Century Proxy Warfare: Confronting Strategic Innovation in a Multipolar World Since the 2011 NATO Intervention. New America Foundation. https://www.newamerica.org/international-security/reports/twenty-first-centuryproxy-warfare-confronting-strategic-innovation-multipolar-world/, accessed July 10, 2020

Rothstein, R. 1968. Alliances and Small Powers. New York: Columbia University Press.

Sabaratnam, M. 2011. IR in Dialogue...but Can We Change the Subjects? A Typology of Decolonising Strategies for the Study of World Politics. Millennium: Journal of International Studies 39 (3): 781-803.

Sadiki, Larbi. 2020. Regionalism in Crisis: GCC Integration without Democracy. The International Spectator 55 (2): 17-33.

Sadiki, L., and L. Saleh. 2020. The GCC in Crisis: Explorations of 'Normless-ness' in Gulf Regionalism. The International Spectator 55 (2): 1-16.

Salisbury, P. (2020) Risk Perception and Appetite in UAE Foreign and National Security Policy. Chatham House. https://www.chathamhouse.org/publication/risk-in-uae-salisbury, Accessed 7 July 2020.

Seth, S., ed. 2013. Postcolonial Theory and International Relations: A Critical Introduction. London: Routledge.

Spivak, Gayatri Chakravorty. (1990). The Postcolonial Critic: Interviews, Strategies, Dialogues. Ed: Sarah Harasym. London: Routledge.

Stockholm International Peace Research Institute (SIPRI). 2021. International Arms Transfers Level Off After Years of Sharp Growth; Middle Eastern Arms Imports Grow Most, Says SIPRI. 15 March, https://www.sipri.org/media/press-release/2021/international-arms-transfers-level-afteryears-sharp-growth-middle-eastern-arms-imports-grow-most, accessed 28 June 2021.

Thurer, Daniel. (1998). "The Perception of Small States: Myth and Reality." In Small States Inside and Outside the European Union: Interests and Policies, Ed. Laurent Goetschel. Dordecht: Springer Science+Media.

Towers, L. Nicole. (2018) Socotra is Finally Dragged into Yemen's civil war, Ripping Apart the Island's Way of Life. The Independent, 10 May, https://www.independent.co.uk/news/world/ middle-east/socotra-yemen-civil-war-uae-miltary-base-island-life-emirates-a8342621.html. Accessed 5 September 2020.

Ulrichsen, Kristian Coates. (2012). Small States with a Big Role: Qatar and the United Arab Emirates in the Wake of the Arab Spring. Discussion Paper. Durham University: HH Sheikh Nasser AlSabah Programme, Durham.

Ulrichsen, K.C. 2014. Qatar and the Arab Spring. Oxford: Oxford University Press.

Ulrichsen, K.C. 2015. The Gulf States in International Political Economy. London: Palgrave.

Ulrichsen, K.C. 2020. Qatar and the Gulf Crisis: A Study of Resilience. Oxford: Oxford University Press.

US Department of State. (2018) Report on International Religious Freedom: United Arab Emirates, https://www.state.gov/reports/2018-report-on-international-religious-freedom/united-arab-emira tes/, accessed 4 September 2020.

Wong, Poh-Kam, Yuen-Ping Ho, and Annette Singh. 2007. Towards an 'Entrepreneurial University' Model to Support Knowledge-Based Economic Development: The Case of the National University of Singapore. World Development 35 (6): 941-958. 
Worth, Robert F. (2018). How a Ransom for Royal Falconers Reshaped the Middle East. The New York Times, 14 March. https://www.nytimes.com/2018/03/14/magazine/how-a-ransom-for-royal-falco ners-reshaped-the-middle-east.html, accessed 9 July 2020.

Publisher's Note Springer Nature remains neutral with regard to jurisdictional claims in published maps and institutional affiliations. 